\section{Landscape Irrigation and Water Conservation in Urban Areas: An Analysis of Information-based Strategies}

\author{
Chengyan Yue ${ }^{1,2}$, Manlin Cui ${ }^{2}$, Xiangwen Kong ${ }^{2}$, Eric Watkins ${ }^{1}$, \\ and Mike Barnes ${ }^{1}$
}

ADDITIONAL INDEX WORDS. behavior change, demand-side management, outdoor water conservation

Summary. Outdoor water use, especially for lawn and landscaping irrigation, accounts for a substantial proportion of residential water use and often peaks during summer months. Understanding how to reduce outdoor water use can play a critical role in balancing the increasing demand for and subsequent protection of water resources. This study aims to find out if information-based strategies can be effective in reducing homeowners' water use as well as identifying the key determinants that can enhance water conservation campaigns. Using online survey data from 2077 randomly selected urban homeowners with home lawns in a relatively water-rich state, we found that social norm-based information is generally more effective to promote household water conservation behavior than education information. Moreover, the results showed that the households' water-saving actions, lawn watering knowledge, awareness for local water scarcity, attitudes toward water conservation, socio-demographics, and landscape characteristics all play a role in determining household water conservation intention.

I ncreased population and public demand for water resources has raised public concerns about water scarcity (Brookshire et al., 2004; Buurman et al., 2017; Dieter et al., 2018). In the United States, 40 states are expected to have water shortages that are not related to drought by 2024 (U.S. Government Accountability Office, 2014). In response to these concerns, a variety of water conservation initiatives have been performed in the United States, such as installing WaterSense-labeled and other waterefficient appliances and minimizing or eliminating landscape irrigation in terms of domestic water use; subsequently, residential per capita water

Received for publication 29 Nov. 2021. Accepted for publication 23 Dec. 2021.

Published online 18 February 2022.

${ }^{1}$ Department of Horticultural Science, University of Minnesota, Twin Cities, 1970 Folwell Avenue, St. Paul, MN 55108

${ }^{2}$ Department of Applied Economics, University of Minnesota, Twin Cities, 1994 Bufford Avenue, St. Paul, MN 55108

This research was funded by Minnesota Metropolitan Council.

C.Y. is the corresponding author. E-mail: yuechy@umn.edu.

This is an open access article distributed under the CC BY-NC-ND license (https://creativecommons. org/licenses/by-nc-nd/4.0/).

https://doi.org/10.21273/HORTTECH05001-21 use has declined significantly (Brelsford and Abbott, 2017; DeOreo et al., 2016; Dieter et al., 2018; U.S. Geological Survey, 2014). However, these strategies do not ensure longterm relief for water shortages; in fact, the effect on reducing the water demand has a limit, especially in urban areas where the population is rapidly growing (Finley and Basu, 2020). This is the case even in regions with abundant water supplies (Minnesota Department of Natural Resources, 202 la; Takacs, 2018). Furthermore, a recent report by Phyn (2020) found that U.S. households increased their daily water use by $21 \%$ during the COVID-19 crisis because people spent more time at home.

Because lawns and gardens provide households with outdoor spaces for sports and leisure activities (Barnes et al., 2020) and help mitigate environmental impacts of urbanization (Monteiro, 2017), Americans continue to use significant amounts of water on their lawns and landscapes. The water use of a U.S. household is estimated to be 320 gal per day; of this amount, $\approx 30 \%$ is for outdoor purposes and overwhelmingly dominated by watering lawns and gardens (Cole and Stewart, 2013; U.S. Environmental Protection Agency, 2013). Water use for landscape irrigation can be even higher in arid and semi-arid regions; for more water-intensive landscapes of the United States, $\approx 40 \%$ to $75 \%$ of the total domestic water supply is used for landscape irrigation (Maupin et al., 2014). The average American household uses more water on lawns and landscapes than for showering and laundry combined (U.S. Environmental Protection Agency, 2021a). Home lawns and landscapes are often overly watered (Maupin et al., 2014; Minnesota Department of Natural Resources, 2021a), and the adoption of automatic landscape irrigation systems (sprinklers) is another reason why outdoor water consumption achieves record peaks. A household with an automatic landscape irrigation system that is not properly maintained and operated can waste up to $25,000 \mathrm{gal}$ of water annually (U.S. Environmental Protection Agency, 2021b).

Water conservation can relieve water demand stress and is of particular interest because it is a low-cost option that has diverse environmental benefits compared with other supply-side water management plans (Brooks et al., 2006; Inman and Jeffrey, 2006). Outdoor water use is a major source of peak demand, especially during hot, dry weather; therefore, it is often a target for water conservation campaigns (Renwick and Green, 2000). In practice, outdoor water use is generally the first to be reduced during droughts or other shortages because it is easier to adjust than indoor water use (U.S. Environmental Protection Agency, 2016). There is an opportunity to save an even greater volume of water by reducing water used on Americans' home lawns and landscapes. Confronted with excessive irrigation

\section{Units}

To convert U.S. to SI, multiply by

\begin{tabular}{llll} 
multiply by & U.S. unit & SI unit & multiply by \\
\hline 0.4047 & $\operatorname{acre}(\mathrm{s})$ & ha & 2.4711 \\
3.7854 & $\mathrm{gal}$ & $\mathrm{L}$ & 0.2642 \\
\hline
\end{tabular}

To convert SI to U.S., multiply by

Hortlechnology $\cdot$ April $202232(2)$ 
demands, what conservation strategies can draw households' attention to the pressing need of further outdoor water use reductions?

Education campaigns that engage the public on water conservation concerns are one of the most extensively used policy instruments and have a long history of promoting water conservation by alerting residents about water shortages and providing detailed water-saving suggestions (Lant, 1993; Russell and Fielding, 2010; Schultz, 2002). This approach suggests that people who engage in fewer water-saving practices are often unaware of water scarcity problems. Additionally, individuals' water-saving behaviors are constrained by a lack of knowledge about what types of adaptions can be made and how, thus eliciting a knowledge deficit (Schultz, 2002). Therefore, by filling this knowledge gap through education campaigns, individuals can be led to conserve water, and the key factor for those education campaigns to succeed is to learn necessary knowledge for carrying out watersaving behaviors as well as why water conservation is important (CorralVerdugo et al., 2002). However, the effectiveness of using education tools to change water use behaviors is mixed (Landon et al., 2016). Some researchers have found water-saving signage at the point of purchase can impact consumers' landscape plant purchasing decisions (Knuth et al., 2020). Some argue that education campaigns are likely necessary but not sufficient to promote behavior changes on their own (Beattie, 2010; Dolnicar and Hurlimann, 2010). A study of an education campaign through media broadcasts has shown there is no significant lagged effect, suggesting that the influence of education efforts lasts only as long as publicity continues (Billings and Day, 1989; Fielding et al., 2013); therefore, the education campaign requires a long-term goal of creating and maintaining lasting behavior change.

Another body of literature in the residential water conservation field has examined the effects of feedback information, which is known to address the information deficit, on future behavior changes (Schultz et al., 2016). Providing feedback information refers to informing households about their water usage with the intention of influencing subsequent water use (Abrahamse et al., 2005). Some studies have shown that providing household consumption information can have an immediate impact on water use, and households that received water use data significantly reduced their water consumption (Boyle et al., 2013; Nguyen et al., 2018; Seyranian et al., 2015; Tom et al., 2011). However, the results are mixed, with some studies concluding that descriptive information does not necessarily influence consumers' decisions and that the effects could be relatively ephemeral (Fielding et al., 2013; Schultz et al., 2007).

To enhance the effect of feedback information on behavior changes, strategies that deliver water consumption information in the context of norms of behaviorally relevant groups are often adopted. Leveraging social norms to encourage behavioral changing in real-world contexts has a long tradition of addressing environmental and social sustainability issues (Schultz et al., 2016), such as the focus theory of normative conduct (Cialdini et al., 1990) and community-based social marketing (McKenzie-Mohr, 2000). Based on the social comparison theory of Festinger (1954), individuals tend to behave in a way that is consistent with that of their peers. Studies have consistently shown that providing information to individuals that describes their behaviors in relation to that of their peers will cause individuals to alter their behavior to be more closely aligned with that of their peer group (Cialdini et al., 2006; Fielding et al., 2013; Schultz et al., 2007, 2016). Specifically, water conservation research has suggested social comparison information was effective in significantly reducing water consumption (Beal et al., 2013). Studies of applying social comparisons further indicated that information alone is not sufficient to influence behavior changes; instead, the information must be presented in a way that activates specific motivational processes (Schultz et al., 2007, 2016). Moreover, such strategies can be combined with other financial tools to create a cascade of improvements. Strategies supplemented with rebates have been used often; for example, daily water use feedback information combined with a rebate has reduced households' water usage by $30 \%$ (Clark and Finley, 2008; Geller et al., 1982; Iglesias and Blanco, 2008).
Additionally, because promoting water-saving behavior is a complex task, it is necessary for policymakers to understand what factors shape household water conservation behavior. In general, research studies of the determinants of water conservation behavior fall into two broad categories: 1) studies focusing on knowledge, attitudes, and beliefs and 2) studies focusing on economic and socio-demographic factors. Although positive attitudes toward water conservation and watersaving appliances are linked to households' water-saving behavior, households' socio-demographic backgrounds have a varied impact on water conservation. Because the amount of water used outdoors is also dictated by lot size and the vegetative makeup of the landscape (Syme et al., 2004), it is also necessary to consider households' landscape characteristics.

Urban water conservation is an important issue even in water-rich regions; however, little evidence exists to validate the effectiveness of policy measures to conserve water in cities located outside of traditionally waterscarce regions. Historically, Minnesota has been recognized as a waterrich state with substantial groundwater and surface water supplies and adequate precipitation. However, the growing population of Minnesota consumes water faster than some aquifers can replenish, and some areas are beginning to feel water demand stress from water quality and/or quantity issues, such as the fast-growing urban centers in the Twin Cities Metropolitan area (Minnesota Department of Natural Resources, 2021a). Groundwater usage in Minnesota has increased by $35 \%$ since the 1990 s, and it continues to increase (Minnesota Environmental Quality Board, 2015). In 2021, Minnesota issued drought warnings in mid-July, and many cities imposed watering restrictions (odd/ even day restrictions or restricted hours) on residential landscapes as drought conditions continued (Minnesota Department of Natural Resources, 2021 b). Water scarcity is a serious issue for arid regions where unsustainable water consumption is a real challenge; however, regions with abundant water also have concerns about their current and future water use (Takacs, 2018).

This study builds on previous studies and aimed to find strategies 
that would be best for promoting water-saving behavior among U.S. urban residents and identified the key determinants for successful water conservation campaigns. This includes households' watering-saving actions, lawn-watering knowledge, awareness of local water scarcity, attitudes toward water conservation, socio-demographics, and landscape characteristics. Specifically, there were three hypotheses that we tested: 1) both education information and social norm-based information have effects on promoting watersaving intentions; 2) adding financial incentives such as rebates to social norm-based information can achieve greater effectiveness when promoting water conservation; and 3) water-saving intentions are influenced by past watersaving actions, lawn-watering knowledge, awareness of local water scarcity, attitudes toward water conservation, socio-demographics, and landscape characteristics.

\section{Methods}

Data collection. To identify feasible and effective ways to improve residents' water conservation efforts in the Minneapolis-Saint Paul metropoli$\tan$ area, especially their lawn-watering practices, we conducted an online survey targeting homeowners with home lawns in the seven-county metropolitan area in Minnesota during 2020-21. There were three screening questions for individuals willing to participate in the survey. Participants must be at least 18 years old, they should have a home lawn, and they should be responsible for maintaining their home lawns instead of hiring others to perform the maintenance. In addition to these screening questions, we also included attention check questions and implemented a survey duration check. Regarding the attention check question, participants were asked to select a specific response from the available options; those who failed this check were excluded from the final sample. Those participants who completed the survey within less than one-third the average time were excluded from the final sample.

Based on official statistics, Minneapolis-Saint Paul-Bloomington, Minnesota-Wisconsin metropolitan area (MN-WI metro area) comprised 86\% of the population within its seven counties in 2019 (U.S. Census Bureau, 2020). The sample of 2077 participants was provided by Qualtrics (Seattle, WA), a professional survey company; this sample was selected randomly from Anoka, Carver, Dakota, Hennepin, Ramsey, Scott, and Washington counties. The proportion of the sample from each county was aligned with the population proportion of the $\mathrm{MN}-\mathrm{WI}$ metro area. Our study passed the human subject review (Institutional Review Board approval number: STUDY00010003).

We included three water conservation messages aiming to influence the intentions to reduce water use (Supplemental Material 1). To address the knowledge deficit, message A was a "use water wisely" message that included a piece of general information about why one should use water wisely and several tips for conserving water. Tips included items such as washing a car using a bucket instead of a hose, storing runoff in rain barrels and using it to water gardens, as well as how much water could be saved in each scenario. To deal with the information deficit, we adopted the social norm comparison approach and further combined it with a rebate. Message B, which comprised a home water use comparison, provided information regarding a household's water consumption and how it compares to that of the neighbors. Message C, which comprised a home water use comparison and rebate, offered an additional rebate incentive for reducing water use. The more they save water during the current measurement period compared with the last measurement period, the higher the rebate values they would receive. These messages were adapted from previous literatures. Specifically, message A was from a study of household water conservation conducted in Singapore (Goette et al., 2019). Messages $\mathrm{B}$ and $\mathrm{C}$ were adapted from research of how households respond to information and monetary incentives involving electricity consumption in India (Sudarshan, 2017).

To determine the effectiveness of the three water conservation messages, each participant was randomly assigned to receive one of the three messages during the survey distribution. We further tested and found there were no significant differences in socio-demographics and landscape characteristics across three groups. After reading the water conservation messages, each participant was asked to choose the degree of intention to reduce water use based on a 7-point Likert-type scale ranging from "very unlikely" to "very likely." According to the theory of planned behavior, intentions, which reflect a motivation or plan to engage in an action, are the most immediate predictors of behavior (Ajzen, 1991).

Additionally, we gathered information about the participants' watersaving practices, lawn knowledge, and awareness of local water scarcity using yes/no questions. We also gathered information about their attitudes toward water conservation and water-efficient technology using a 7-point Likert-type scale ranging from "strongly disagree" to "strongly agree." The socio-demographic characteristics of participants as well as their home landscape characteristics were also collected during the survey.

EMPIRICAL ESTIMATION STRATEGY. Because the dependent variable of interest is a discrete and ordinal variable that was measured using a 7 point Likert-type scale, we used ordered probit models to explore the effectiveness of each message and how participants' intentions to reduce water use were affected by their watersaving actions, lawn-watering knowledge, awareness of local water scarcity, attitudes toward water conservation, socio-demographics, and landscape characteristics.

Ordered probit models are a widely used approach to estimate models with an ordinal dependent variable that is not continuous (Greene and Hensher, 2010). Examples include rating systems (poor, fair, good, excellent), opinion scales ranging from strongly disagree to strongly agree, ranking, grades, bound ratings, and others. The ordered probit model originated from biostatistics but was later brought into the social sciences (Aitchison and Silvey, 1957; McKelvey and Zavoina, 1975).

The central idea of an ordered probit model is that there is a latent variable underlying the ordinal observed outcome. The latent variable can be expressed by a linear combination of some predictors and an error term that has a standard normal distribution. Ordered probit models allow us to interpret the effects of predictors on the latent 
variable. Therefore, we estimated the following model:

$$
\begin{aligned}
Y_{i}^{*}= & \beta_{1} K_{i}+\beta_{2} A_{i}+\beta_{3} X_{i}+\beta_{4} L_{i}+\varepsilon_{i} \\
& \varepsilon_{i} \sim \text { Normal }(0,1)
\end{aligned}
$$

where $Y_{i}^{*}$ is the unobserved latent variable representing the true level of intention to reduce water use for participant $i ; K_{i}$ represents the variables for participants' water-saving practices, lawn-watering knowledge, and awareness of local water scarcity; $A_{i}$ is a vector of variables representing participants' attitudes toward water conservation and water-efficient technology; $X_{i}$ is a vector of participants' socio-demographic variables, including expected years living at the current residence, age, sex, education, marital status, income, and household size; $L_{i}$ represents a set of landscape characteristics, such as lawn size, frequency of lawn watering, type of grass and type of soil at the home lawn, and others; and $\varepsilon_{i}$ is an error term assumed to follow a standard normal distribution. We calculated heteroskedasticity-robust SES for all regressions to improve efficiency.

The link between the latent variable and the observed dependent variable is:

$$
\begin{gathered}
Y_{i}=j \text { if } \mu_{j-1}<Y_{i}^{*}<\mu_{j} \\
j=1,2,3,4,5,6,7 \\
\mu_{o}=0, \mu_{7}=\infty
\end{gathered}
$$

where $Y_{i}^{*}$ is participant $i$ 's response to the Likert-type scale survey question, which is the observed dependent variable; $j$ is the 7 -point rating; and $\mu_{j}$ is the cut-point or threshold parameter. Thresholds divide the real line into a series of intervals corresponding to various ordered categories and are estimated to match the probabilities associated with each ordered category. The probability that observation $i$ will choose the degree $j$ is:

$$
\begin{aligned}
& \operatorname{Pr}\left(Y_{i}=j\right) \\
= & \operatorname{Pr}\left(\mu_{j-1}<Y_{i}^{*}<\mu_{j}\right) \\
= & \operatorname{Pr}\left(\mu_{j-1}<\beta_{1} K_{i}+\beta_{2} A_{i}+\beta_{3} X_{i}+\beta_{4} L_{i}+\varepsilon_{i}<\mu_{j}\right) \\
= & \operatorname{Pr}\left(\mu_{j-1}-\beta_{1} K_{i}-\beta_{2} A_{i}-\beta_{3} X_{i}-\beta_{4} L_{i}\right. \\
& \left.<\varepsilon_{i}<\mu_{j}-\beta_{1} K_{i}-\beta_{2} A_{i}-\beta_{3} X_{i}-\beta_{4} L_{i}\right) \\
= & F\left(\mu_{j}-\beta_{1} K_{i}-\beta_{2} A_{i}-\beta_{3} X_{i}-\beta_{4} L_{i}\right) \\
& -F\left(\mu_{j-1}-\beta_{1} K_{i}-\beta_{2} A_{i}-\beta_{3} X_{i}-\beta_{4} L_{i}\right)
\end{aligned}
$$

where $F$ is the standard normal cumulative distribution function.

\section{Results}

SUMMARY STATISTICS OF SURVEY PARTICIPANTS. Table 1 presents the summary statistics of participants' sociodemographic information. A total of 2077 participants completed the survey. In our sample, nearly half of participants expected to stay at their current residence for at least the next 10 years. The median age range of our participants was 46 to 55 years, and slightly more than $60 \%$ of participants had college diplomas. Approximately $65 \%$ of participants were female and $59 \%$ were married. The median income range was $\$ 65,001$ to $\$ 80,000$, and the average household size was 2.75 people. Although our sample had more participants who were older, married, and had college diplomas than the population in the MN-WI Metro Area (U.S. Census Bureau, 2020), we were confident that that sample was generally representative of homeowners who have home lawns.

Participants' LANDSCAPE CHARACTERISTICS AND LAWN-WATERING PRACTICES. Detailed information about participants' home lawn characteristics and watering practices were collected (Table 2). The majority of participants had a yard of at least 0.25 acres, and $\approx 35 \%$ used an underground/installed automatic irrigation system (sprinkler system). More than half of participants watered their lawn for at least $20 \mathrm{~min}$ in each irrigation zone, and the frequency of lawn watering varied from less than twice per month to more than 13 times per month; fewer than $10 \%$ of participants did not know the answers to these two questions. Approximately $31 \%$ of participants reported that they generally continue to water their lawns until fall. A moderate percentage of participants were unsure about the type of grass (34\%) and the type of soil $(38 \%)$ of their home lawn. Among those who were aware, most participants reported they had a mixture of grasses and clay soil comprising their home lawn.

Moreover, when comparing the frequency and duration of watering home lawns of participants who had an automatic irrigation system and those who did not, we found that participants who had an automatic irrigation system watered their lawns more frequently and for a shorter period of time. Those who did not have an automatic irrigation system watered their lawns less frequently and for a longer period of time. Furthermore, the percentage of participants who did not know the duration of lawn watering was significantly higher than that of those who did not have an autonomous irrigation system (Fig. 1). We have conducted t-tests of these comparisons, and all the differences were significant.

Participants' Water conservation PRACTICES AND ATTITUDES. The results of participants' water-saving practices and attitudes toward water conservation are presented in Table 3 . In general, most participants refrained from watering lawns during and after rain events, and they were aware of the risks of overwatering lawns. Nonetheless, less than $20 \%$ believed Minnesota has water scarcity issues (Table 3, panel A). Statistics suggested that participants were concerned about water scarcity issue, and that they had a positive view of technologies that can help save water (Table 3, panel B). We conducted t-tests and found that participants who received the three messages were not significantly different in terms of their demographics and water conservation practices and attitudes.

Participants' responses to DIFFERENT WATER CONSERVATION INFORMATION. Table 4 compares the average level of intention to reduce water use for the three groups of participants after they read the corresponding message. Overall, participants' intentions to reduce water use would be favorably affected by all three messages, with message $\mathrm{C}$ receiving the highest rating. Specifically, message A (use water wisely), which provided detailed instructions about how to use water wisely, had the least impact on motivating participants to reduce water use. Compared with the results of message A, t-test results showed that message B (water use comparison) and message $\mathrm{C}$ (water use comparison and rebate) had significantly higher impacts on increasing participants' intentions to conserve water. When the additional rebate incentive was added to the comparison information (message $\mathrm{C}$ ), t-test results showed that it did not significantly increase the impact compared with message $B$, which informed participants of their water usage in comparison with that of their neighbors. 
Table 1. Summary of demographic characteristics of participants in the landscape water use survey in the Minnesota seven-county metropolitan area $(N=2077)$. The mean and SD of each variable are reported, as are the frequency and percent for each value.

\begin{tabular}{|c|c|c|c|}
\hline \multirow[b]{2}{*}{ Demographic characteristic } & \multicolumn{3}{|c|}{ Survey participants } \\
\hline & $\begin{array}{c}\text { Mean } \\
(\mathrm{SD})\end{array}$ & No. & $\%$ \\
\hline Expected years living in current home & $2.66(1.46)$ & & \\
\hline $\mathrm{l}=<5$ years & & 612 & 29.47 \\
\hline $2=5-9$ years & & 478 & 23.01 \\
\hline $3=10-14$ years & & 367 & 17.67 \\
\hline $4=15-20$ years & & 241 & 11.6 \\
\hline $5=>20$ years & & 379 & 18.25 \\
\hline Age & $3.82(1.70)$ & & \\
\hline $1=18-25$ years & & 216 & 10.4 \\
\hline $2=26-35$ years & & 358 & 17.24 \\
\hline $3=36-45$ years & & 324 & 15.6 \\
\hline $4=46-55$ years & & 323 & 15.55 \\
\hline $5=56-65$ years & & 464 & 22.34 \\
\hline $6=66-75$ years & & 328 & 15.79 \\
\hline $7=76$ years and older & & 64 & 3.08 \\
\hline Sex & $0.65(0.49)$ & & \\
\hline $1=$ Female & & 1,360 & 65.48 \\
\hline $0=$ Male & & 717 & 34.52 \\
\hline Education & $0.60(0.49)$ & & \\
\hline $1=$ College diploma and higher & & 1,253 & 60.33 \\
\hline $0=$ Other & & 824 & 39.67 \\
\hline Marital status & $0.58(0.49)$ & & \\
\hline 1 = Married & & 1,215 & 58.5 \\
\hline $0=$ Other & & 862 & 41.5 \\
\hline Income & $5.85(2.03)$ & & \\
\hline $1=\leq \$ 15,000$ & & 78 & 3.76 \\
\hline $2=\$ 15,001-\$ 25,000$ & & 81 & 3.9 \\
\hline $3=\$ 25,001-\$ 35,000$ & & 141 & 6.79 \\
\hline $4=\$ 35,001-\$ 50,000$ & & 243 & 11.7 \\
\hline $5=\$ 50,001-\$ 65,000$ & & 270 & 13 \\
\hline $6=\$ 65,001-\$ 80,000$ & & 297 & 14.3 \\
\hline $7=\$ 80,001-\$ 100,000$ & & 345 & 16.61 \\
\hline $8=>\$ 100,000$ & & 622 & 29.95 \\
\hline Household size & $2.75(1.44)$ & & \\
\hline 1 person & & 307 & 14.78 \\
\hline 2 people & & 850 & 40.92 \\
\hline 3 people & & 375 & 18.05 \\
\hline 4 people & & 313 & 15.07 \\
\hline 5 people & & 142 & 6.84 \\
\hline 6 people & & 56 & 2.7 \\
\hline$>7$ people & & 34 & 1.64 \\
\hline
\end{tabular}

FACTORS INFLUENCING PARTICIPANTS' INTENTIONS TO REDUCE WATER USE. Table 5 shows the results of the order probit regressions that examined the effectiveness of each message to improve resident water conservation intentions and how their intentions to conserve water differed based on their water conservation practices, attitudes toward water conservation, socio-demographics, and landscape characteristics. Model 1 shows the main results of the message effectiveness and the factors message $\mathrm{B}$ as the base for the subsample of these two groups (model 4).

Overall, the message effectiveness and the relationships between water conservation intentions and influential factors were consistent across the four specifications. Our main results presented in model 1 show that the effectiveness of message B was significantly higher than that of message $\mathrm{A}$, whereas message $\mathrm{C}$ showed no significant improvement in the effectiveness compared with message B. Regarding participants' demographic characteristics, participants who expected to stay at their current residence for a longer period of time, those who were older, those with a higher income, and larger households were less likely to reduce water use. Conversely, female participants and those with college degrees were more likely to save water. We found no significant influence of marital status on water conservation intentions. Regarding landscape characteristics and lawn-watering practices, we found that participants with larger lawns, those who often had a longer watering duration and watered more frequently, and those who continued to water their lawns in the fall had significantly fewer intentions to reduce water use; however, there were no significant differences in water-saving intentions, whether the lawn had an irrigation system, or the reported grass or soil type for their lawns. Finally, the results revealed that participants who saved water during storms, those who knew the risk of overwatering lawns, those who were aware of the water scarcity issues in the state, those who considered water conservation as more important, and those who had a positive view of water-efficient technology were more likely to reduce water use. Moreover, the interaction terms in model 2 suggested that participants who favored water-efficient technologies were more inclined to conserve water if they often had a longer watering duration compared with those with a shorter watering duration; however, no analogous result was observed in terms of the watering frequency.

The comparison of the effectiveness of the three messages also showed interesting results. Results of model 3 showed that compared with messages B and C, message A was not as effective for reducing water use. However, message $\mathrm{A}$ was more 
Table 2. Descriptive statistics of home lawn-watering practices of participants in the landscape water use survey in the Minnesota seven-county metropolitan area $(\mathrm{N}=2077)$. The frequency and percent for each value are reported.

\begin{tabular}{|c|c|c|}
\hline \multirow[b]{2}{*}{ Watering practices } & \multicolumn{2}{|c|}{ Survey participants } \\
\hline & No. & $\%$ \\
\hline \multicolumn{3}{|l|}{ Lawn size } \\
\hline Less than $1 / 8$ acre $^{z}$ & 559 & 26.91 \\
\hline $1 / 8$ acre & 358 & 17.24 \\
\hline $1 / 4$ acre & 487 & 23.45 \\
\hline $1 / 2$ acre & 269 & 12.95 \\
\hline 1 acre & 103 & 4.96 \\
\hline$>1$ acre & 116 & 5.58 \\
\hline I do not know & 185 & 8.91 \\
\hline \multicolumn{3}{|l|}{ Have an automatic irrigation system } \\
\hline $1=$ Yes & 719 & 34.62 \\
\hline $0=\mathrm{No}$ & 1,358 & 65.38 \\
\hline \multicolumn{3}{|l|}{ Duration of lawn watering } \\
\hline$<5 \mathrm{~min} /$ zone & 205 & 9.87 \\
\hline $5-10 \mathrm{~min} /$ zone & 357 & 17.19 \\
\hline $11-20 \mathrm{~min} / z o n e$ & 499 & 24.03 \\
\hline $21-30 \mathrm{~min} / \mathrm{zone}$ & 435 & 20.94 \\
\hline $31-40 \mathrm{~min} / \mathrm{zone}$ & 159 & 7.66 \\
\hline $41-50 \mathrm{~min} / \mathrm{zone}$ & 69 & 3.32 \\
\hline $51-60 \mathrm{~min} /$ zone & 106 & 5.1 \\
\hline$>60 \mathrm{~min} /$ zone & 89 & 4.29 \\
\hline I do not know & 158 & 7.61 \\
\hline \multicolumn{3}{|l|}{ Frequency of lawn watering } \\
\hline$<2$ times/month & 474 & 22.82 \\
\hline 2-4 times/month & 576 & 27.73 \\
\hline 5-7 times/month & 319 & 15.36 \\
\hline 8-10 times/month & 253 & 12.18 \\
\hline 11-13 times/month & 147 & 7.08 \\
\hline$>13$ times/month & 204 & 9.82 \\
\hline I do not know & 104 & 5.01 \\
\hline \multicolumn{3}{|l|}{ Irrigate home lawn in fall } \\
\hline $1=$ Yes & 651 & 31.34 \\
\hline $0=\mathrm{No}$ & 1,426 & 68.66 \\
\hline \multicolumn{3}{|l|}{ Type of grass of the home lawn } \\
\hline Kentucky bluegrass (Poa pratensis) & 227 & 10.93 \\
\hline Tall fescue (Festuca arundinacea) & 27 & 1.3 \\
\hline Perennial ryegrass (Lolium perenne) & 30 & 1.44 \\
\hline Fine fescue (Festuca ovina) & 36 & 1.73 \\
\hline A mixture of grasses & 1,046 & 50.36 \\
\hline I do not know & 711 & 34.23 \\
\hline \multicolumn{3}{|l|}{ Type of soil of the home lawn } \\
\hline Sand & 427 & 20.56 \\
\hline Loam & 365 & 17.57 \\
\hline Clay & 490 & 23.59 \\
\hline I do not know & 795 & 38.28 \\
\hline
\end{tabular}

${ }^{\mathrm{z}} 1$ acre $=0.4047 \mathrm{ha}$

effective for male participants, participants who did not know their lawn size, those who often had a longer watering duration and watered more frequently, those who preferred water-efficient technology, those who had not taken water-saving actions, and those who were not aware of water scarcity problems. Other characteristics, such as lawn-watering knowledge and water-saving importance, were found to have no significant impact. Estimates of model 4 suggested that compared with message $B$, message $C$ was not more effective in general, but it became more effective for participants who knew their grass type, those who watered longer, and those who did not know their normal watering duration.

\section{Discussion and conclusions}

Increased population, increased irrigation demands, and the growth of industries that require greater water inputs have started to strain global water resources (Brookshire et al., 2004; Dieter et al., 2018). Climate changes and droughts that have occurred in recent years further pose a serious challenge to sustainable development (Cayan et al., 2010; University of Nebraska-Lincoln, 2021). Apart from traditionally water-scarce regions, there is an increasing interest in water conservation campaigns, even in historically water-rich regions. Outdoor water usage is sensitive to climate variations (Mayer et al., 1999) and is closely linked to behavioral factors and cultural expectations of yards (Fielding et al., 2012; Polsky et al., 2014), thus making it an attractive target for water conservation programs. Using data of 2077 randomly selected homeowners from the Twin Cities metropolitan area, where the fast-growing population has started to challenge the city water supply system, we provided evidence of the effectiveness of different informationbased strategies for reducing urban residents' water use intentions and identified the key determinants that could be targeted by water conservation campaigns.

We found that the education and social norm-based messages generated different levels of water conservation intentions. Specifically, regarding the education message (message A: use water wisely), which addressed the knowledge deficit, participants were only slightly likely to lower their water consumption after reading it. This was expected because past research indicated that the efficacy of education campaigns often varies by areas, and that those programs that urge people to conserve water lead to significant water demand reduction only in the western United States, where water shortages are more prevalent (Nieswiadomy, 1992; Renwick and Green, 2000). Nonetheless, this positive intention to conserve water supports the idea that water-saving behaviors usually happen when the nature of water shortages and water-saving options are understood, and the idea that household members believe they can implement at least some of the available water-saving options. 

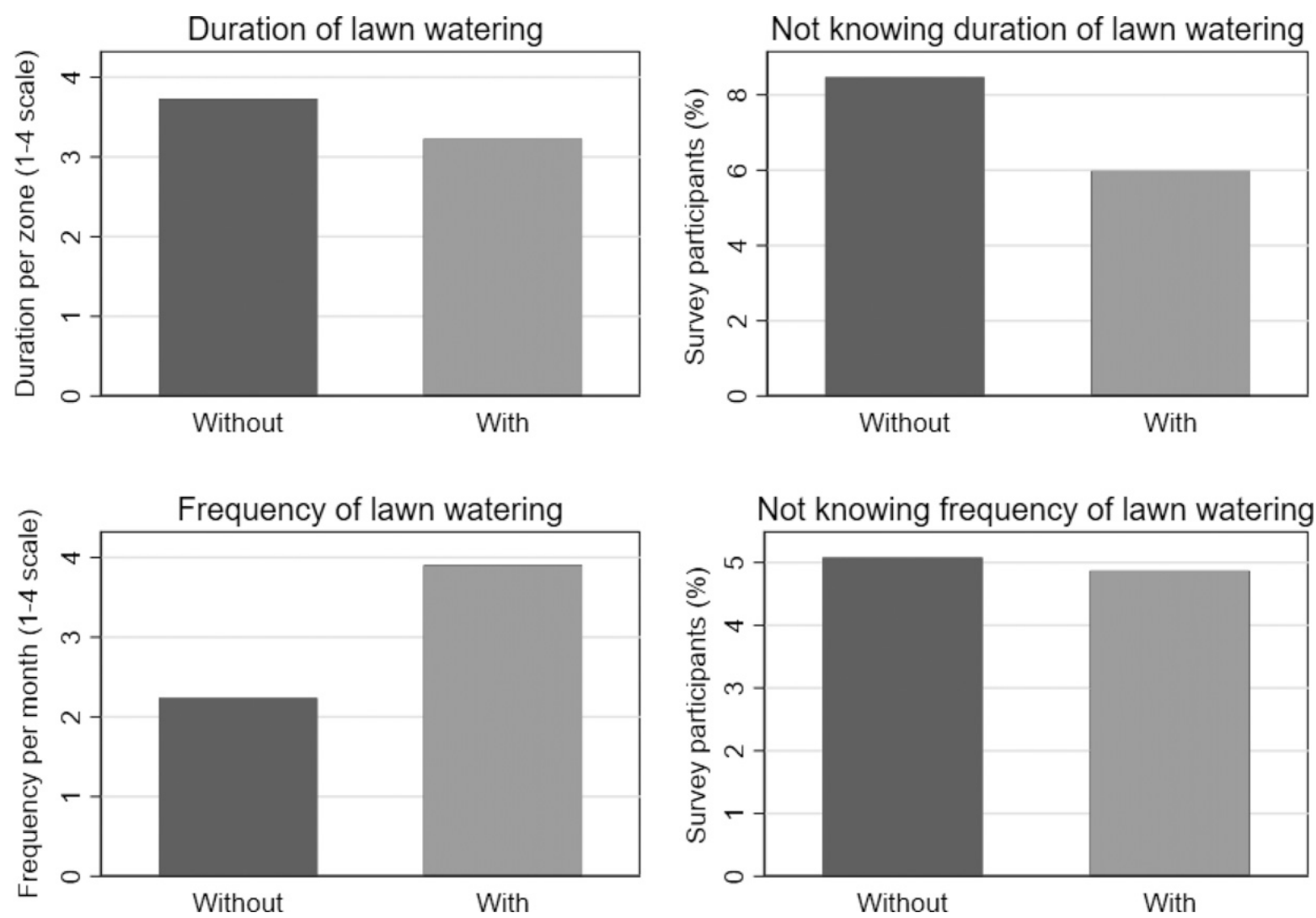

Fig. 1. Comparing lawn-watering practices of participants with and without automatic irrigation systems. The duration of lawn watering has the following values: $1=<5 \mathrm{~min} /$ zone; $2=5-10 \mathrm{~min} / \mathrm{zone} ; 3=11-20 \mathrm{~min} / \mathrm{zone} ;$ and $4=21-30 \mathrm{~min} /$ zone. The frequency of lawn-watering has the following values: $1=<2$ times $/$ month; $2=2-4$ times $/$ month; $3=5-7$ times $/$ month; and $4=8-10$ times/month.

The social norm-based messages that addressed the information deficit in the context of social comparison (message B regarding water use comparison and message $\mathrm{C}$ regarding water use comparison and rebate) practically yielded higher intentions to reduce water use compared with message A. Participants were somewhat likely to reduce water consumption after reading message $B$, and they were slightly more likely to reduce water use after reading message $\mathrm{C}$. This reveals that the normative description feedback information with social comparison and a combination of the feedback information and a rebate will be likely to reduce household water use.
However, the cost-benefit analysis of rebate programs should be considered because message $\mathrm{C}$ showed no significant improvement in water use reductions compared with message B.

The effectiveness of the interventions we found were consistent with those of other studies of social psychology and behavioral economics that

Table 3. Water conservation practices and attitudes toward home lawns of participants in the landscape water use survey in the Minnesota seven-county metropolitan area. Variables in panel A have a value of 1 if the response of the participants is "yes" and a value of 0 if their response is anything other than "yes." Variables in panel B have values based on a 7 -point Likert-type scale, with 1 = "strongly disagree" and 7 = "strongly agree."

\begin{tabular}{|c|c|c|c|}
\hline \multirow[b]{2}{*}{ Watering practices and attitudes } & \multirow[b]{2}{*}{ Description } & \multicolumn{2}{|c|}{ Survey participants } \\
\hline & & Mean & SD \\
\hline \multicolumn{4}{|l|}{ Panel A: Water conservation practices } \\
\hline Water-saving action $(1=$ yes $)$ & $\begin{array}{l}\text { I change how I water my lawn based on the } \\
\text { weather forecast }\end{array}$ & 0.80 & 0.40 \\
\hline Lawn-watering knowledge $(1=$ yes $)$ & I agree that overwatering can damage grass & 0.79 & 0.41 \\
\hline Water scarcity awareness $(1=$ yes $)$ & I believe my state has water scarcity issues & 0.19 & 0.39 \\
\hline \multicolumn{4}{|l|}{ Panel B: Water conservation attitudes } \\
\hline Water-saving importance & Conserving water is important to me & 5.41 & 1.49 \\
\hline Water-efficient technology preference & $\begin{array}{l}\text { I am interested in technology that can help } \\
\text { me optimize the amount of water }\end{array}$ & 5.00 & 1.66 \\
\hline
\end{tabular}


Table 4. Responses to different water conservation information of participants in the landscape water use survey in the Minnesota seven-county metropolitan area. The observations of each group of participants are reported. Means and SD are based on a 7 -point Likert-type scale, with $1=$ "very unlikely" and $7=$ "very likely."

\begin{tabular}{lrr}
\hline & \multicolumn{2}{c}{ Survey participants } \\
\cline { 2 - 3 } After reading this message, how likely are you to attempt to reduce water use? & No. & \multicolumn{1}{c}{ Mean } \\
\hline Panel A: Education information & 699 & 5.19 \\
Message A: Use water wisely message & & 686 \\
Panel B: Social norm-based information & 692 & 5.38 \\
Message B: Home water-use comparison & 5.51 \\
Message C: Home water-use comparison and rebate & 696 \\
\hline
\end{tabular}

used information-based approaches to achieve behavior changes regarding residential water conservation (Bernedo et al., 2014; Ferraro et al., 2011). Such information-based strategies are also widely used to promote energy conservation. For example, Allcott (2011) identified a substantial and cost-effective intervention to reduce energy consumption: residential utility customers received home energy report letters comparing their electricity use to that of their neighbors. Additionally, Dolan and Metcalfe (2015) found large financial rewards work well for reducing energy consumption. Because of the relatively small rebate reward $(\$ 5$ for every $5 \%$ reduction) offered during our study, it was reasonable that the addition of that rebate was not quite effective. Although providing information about best practices to reduce lawn water use can have some effect, efforts should focus on approaches that directly create incentives for reduced lawn water use, such as how water use compares to that of the neighbors. However, how much the intentions to reduce water use can be translated into real water-saving behaviors remains unknown.

We concluded that the effectiveness of the strategies would vary depending on household water-saving practices, knowledge, awareness of local water scarcity, and water-saving attitudes. The results are consistent with findings in the literature showing people's past experiences with and awareness of drought, and that their involvement with water conservation efforts and their interactions with plants impact how they value the water needs of plants (Behe et al., 2018; Knuth et al., 2018a, 2018 b, 2019). Past water-saving practices and lawn-watering knowledge of the households had different influences on the results. Because the education message encourages households to save water and provides water-saving suggestions that can be performed easily, regardless of their knowledge of watering lawns, it is more effective for those who are not aware of water storage issues and have not performed water-saving actions before; however, the success of the social norm-based strategies relied on residents' knowledge of water conservation. Nonetheless, residents' water-saving attitudes and understanding of local water scarcity issues have impacts on water-saving intentions, which could be an important target of water-saving interventions. Research has consistently shown that positive attitudes toward water conservation and water-saving appliances are linked to households' water-saving behaviors (Dolnicar and Hurlimann, 2010; Syme et al., 2004; Willis et al., 2011). These findings highlight the value of policies that promote long-term education programs that shift how people think about and use water.

Additionally, we found homeowners' sociodemographic, attitudes, and past knowledge and the characteristics of the landscape are highly relevant to understanding outdoor water conservation intentions. First, it has been observed that households' water saving-intentions are influenced by their income. Past literatures have summarized that household income often has diverging effects on water conservation decisions: whereas more affluent households can afford to invest in water-saving technologies, a diminishing marginal utility of income indicates that wealthy households are less motivated to conserve water and face a higher opportunity cost because of the time needed to install water-saving equipment or engage in time-consuming water conservation activities (Millock and Nauges, 2010). Our results indicate that high-income households would find it more costly to adopt conservation behaviors that involve greater time investments in water-using activities. Second, age has been found to influence participants' water-saving intentions. The effects of age on water conservation correspond to aspects of the household life cycle; for example, elderly households may use less water for recreation purposes (Fielding et al., 2012). This was also observed by our data; we found that older participants had a shorter water duration and watered less frequently (on average) than younger participants (not reported). Third, although both the education message and social normbased messages are more effective for females in general, the education message was more effective for males, who have often have more hands-on experience. Fourth, better-educated households are expected to be more likely to conserve water because saving water requires understanding watering requirements for different landscapes as well as water-saving options (De Oliver, 1999; Lam, 2006). For other socio-demographic variables, we found a negative effect of large households and no significant effect of marital status, which was different from the results of Millock and Nauges (2010) and Saurí (2013), who found a positive relationship between household size and the adoption of water-saving technologies, and the results of Aprile and Fiorillo (2017), who found that married couples were less inclined to adapt their water conservation habits.

Reported landscape characteristics were also shown to be important to water conservation practices. First, larger lawns generally require more inputs than smaller ones; therefore, it would be more expensive to adopt water-saving practices and equipment for those with larger lawns. Similarly, a higher frequency of lawn watering reflects a higher water requirement that may become habitual; however, households with a longer watering duration would choose to conserve 
Table 5. Factors influencing participants' responses to different water conservation information during the landscape water use survey in the Minnesota seven-county metropolitan area. Statistics show coefficients and robust SE (in parentheses) from ordered probit regression models. The dependent variable is the participants' self-reported likelihood of reducing water use.

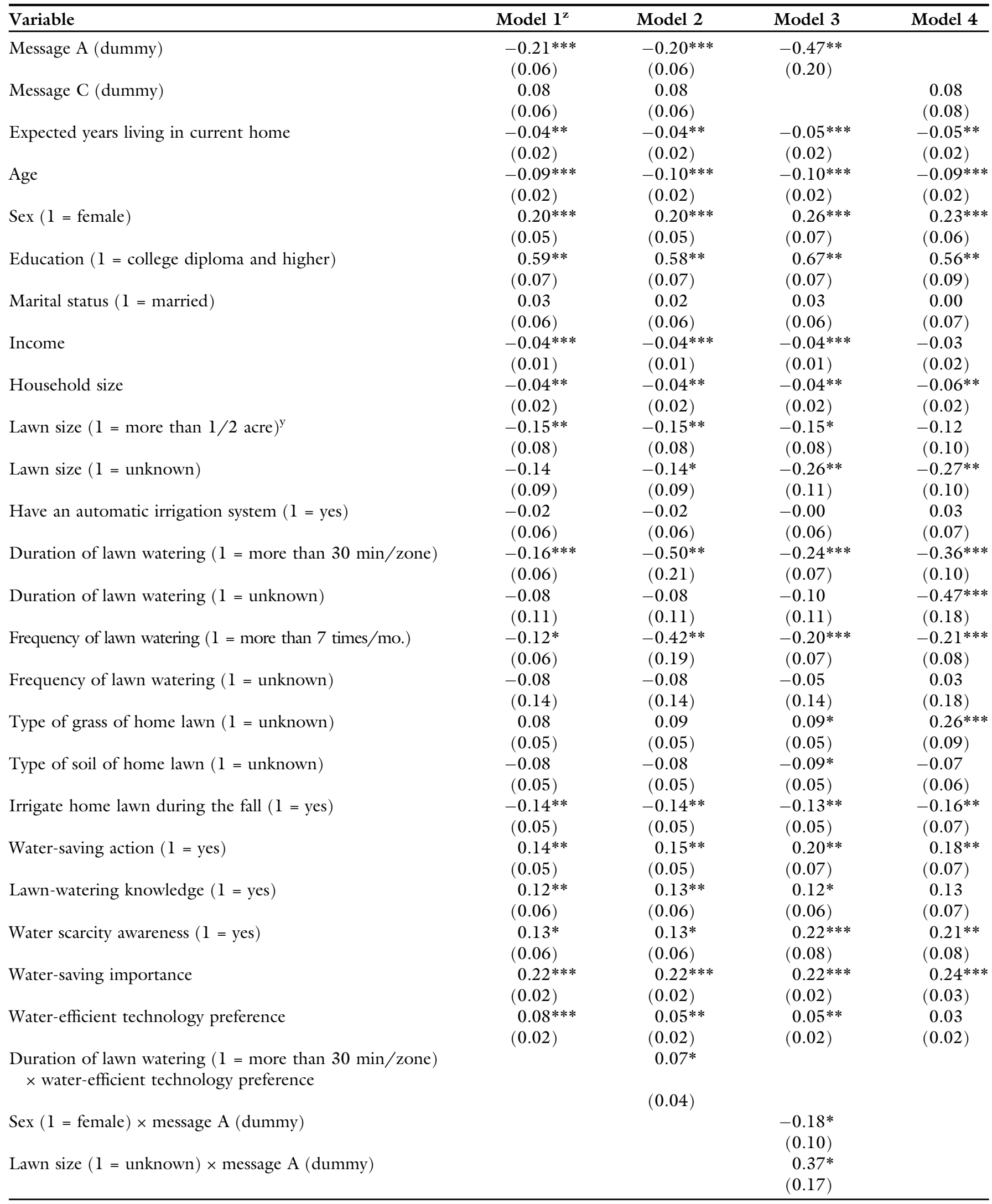


Table 5. (Continued)

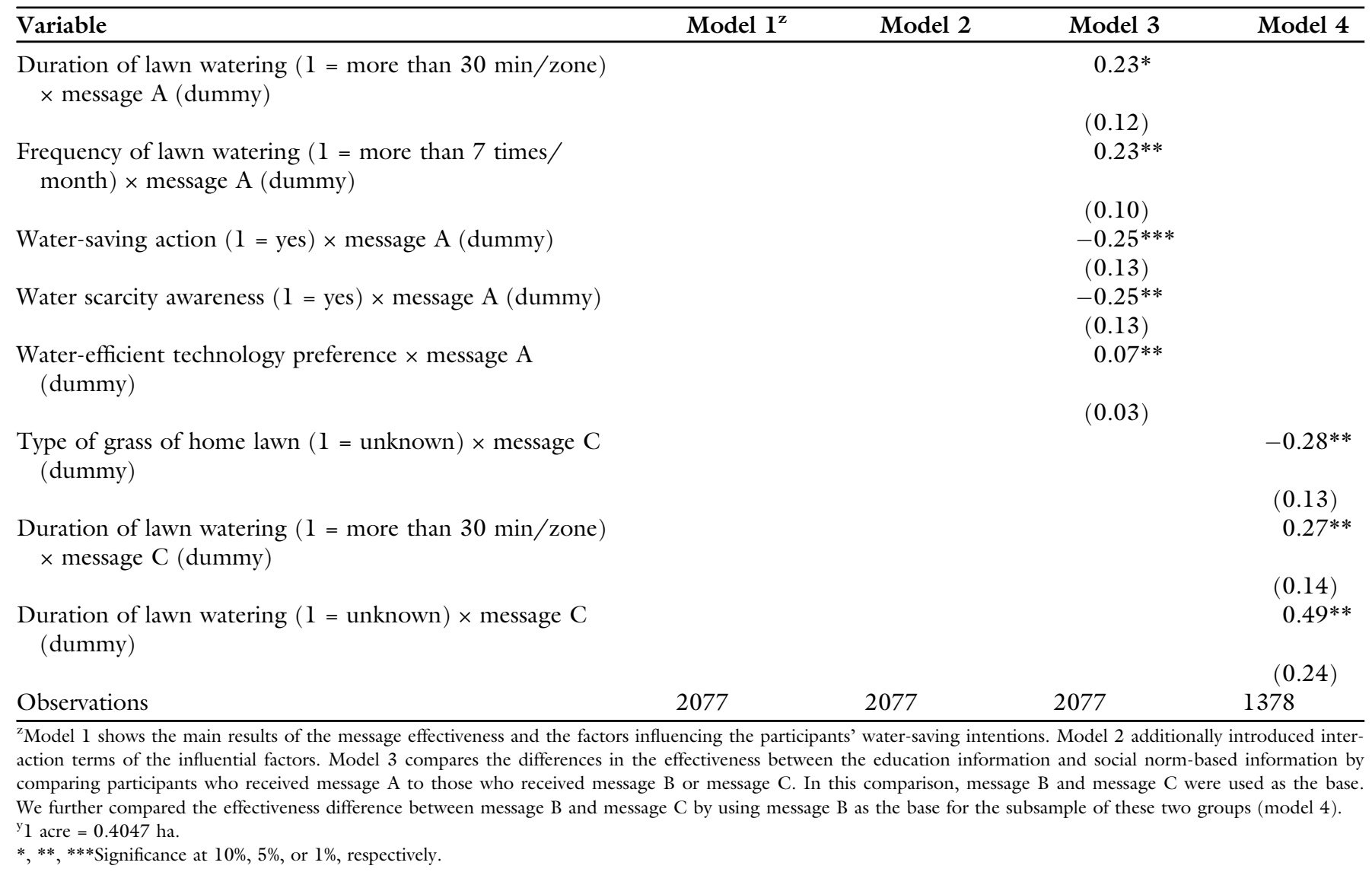

water if they favor water-efficient technologies (Beal et al., 2013; Fan et al., 2017; Gilg and Barr, 2006). Additionally, the type of turfgrass present in a lawn determines the water needed for optimal growth, and the soil's ability to retain water is strongly related to its type (i.e., the particle size). Recent literature has shown the utility of turfgrass species as a wateruse reduction strategy. For example, kentucky bluegrass (Poa pratensis) and perennial ryegrass (Lolium perenne) are popular cool-season turfgrasses that require more water $(\mathrm{Fu}$ et al., 2004; Su et al., 2008), whereas low-input turfgrasses such as hard fescue (Festuca brevipila) and colonial bentgrass (Agrostis capillaris) can perform well with less water (Braun et al., 2020; Hugie and Watkins, 2016; Watkins et al., 2011).

These findings highlight the importance of information-based behavioral intervention policies that can be used to reduce the use of natural resources, further the understanding of the role of these social, psychological, and sociodemographic factors in influencing outdoor water use, and contribute to a body of knowledge that informs the development of effective water conservation policies. To address increasing water demands, it is important to encourage water conservation by asking people to be wise about watering practices for home lawns and to maintain a sustainable and eco-friendly landscape.

Our results have important implications for municipalities and utility companies when designing demand-side water conservation programs. In water-rich urban areas, social norm-based interventions are generally more effective for promoting water-saving intentions than educational interventions. Adding rebates of moderate value to social norm-based interventions does not effectively achieve significantly greater conservation intentions in such areas. Program designers should focus on using social norm interventions to encourage conservation behaviors. However, when considering a water conservation program, policy designers should consider the factors that have roles in determining households' water-saving intentions. Water conservation programs can be more effective if they can also increase households' lawnwatering knowledge, raise their awareness of the local water scarcity issue, develop households' positive attitudes toward water conservation, and can involve customized interventions based on households' socio-demographics and landscape characteristics.

\section{Literature cited}

Abrahamse, W., L. Steg, C. Vlek, and T. Rothengatter. 2005. A review of intervention studies aimed at household energy conservation. J. Environ. Psychol. 25(3): 273-291, https://doi.org/10.1016/j. jenvp.2005.08.002.

Aitchison, J. and S.D. Silvey. 1957. The generalization of probit analysis to the case of multiple responses. Biometrika 44 (1/2):131-140, https://doi.org/10.2307/ 2333245 .

Ajzen, I. 1991. The theory of planned behavior. Organ. Behav. Hum. Decis. Process. 50(2):179-211, https://doi. org/10.1016/0749-5978(91)90020-T. 
Allcott, H. 2011. Social norms and energy conservation. J. Public Econ. 95(9-10): 1082-1095, https://doi.org/10.1016/ j.jpubeco.2011.03.003.

Aprile, M.C. and D. Fiorillo. 2017. Water conservation behavior and environmental concerns: Evidence from a representative sample of Italian individuals. J. Clean. Prod. 159:119-129, https://doi.org/10. 1016/j.jclepro.2017.05.036.

Barnes, M.R., K.C. Nelson, and M.E. Dahmus. 2020. What's in a yardscapes? A case study of emergent ecosystem services and disservices with resident yardscape discourses in Minnesota. Urban Ecosyst. 23: 1167-1179, https://doi.org/10.1007/ s11252-020-01005-2.

Beal, C.D., R.A. Stewart, and K. Fielding. 2013. A novel mixed method smart metering approach to reconciling differences between perceived and actual residential end use water consumption. J. Clean. Prod. 60:116-128, https://doi. org/10.1016/j.jclepro.2011.09.007.

Beattie, G. 2010. Why aren't we saving the planet? A psychologist's perspective. Routledge, London, UK, https://doi. org/10.4324/9780203840078.

Behe, B.K., M. Knuth, C.R. Hall, P.T. Huddleston, and R.T. Fernandez. 2018. Consumer involvement with and expertise in water conservation and plants affect landscape plant purchases, importance, and enjoyment. HortScience 53(8):1164-1171, https://doi.org/10.21273/HORTSCI13 119-18.

Bernedo, M., P.J. Ferraro, and M. Price. 2014. The persistent impacts of normbased messaging and their implications for water conservation. J. Consum. Policy 37 (3):437-452, https://doi.org/10.1007/ s10603-014-9266-0.

Billings, R.B. and W.M. Day. 1989. Demand management factors in residential water use: The southern Arizona experience. J. Amer. Water Works Assoc. 81 (3):58-64, https://doi.org/10.1002/ j.1551-8833.1989.tb03182.x.

Braun, R.C., A.J. Patton, E. Watkins, P.L. Koch, N.P. Anderson, S.A. Bonos, and L.A. Brilman. 2020. Fine fescues: A review of the species, their improvement, production, establishment, and management. Crop Sci. 60(3):1142-1187, https://doi.org/10.1002/csc2.20122.

Brooks, T.M., R.A. Mittermeier, G.A. da Fonseca, J. Gerlach, M. Hoffmann, J.F. Lamoreux, C.G. Mittermeier, J.D. Pilgrim, and A.S. Rodrigues. 2006. Global biodiversity conservation priorities. Science 313(5783):58-61, https://doi.org/ 10.1126/science.1127609.
Brookshire, D.S., B. Colby, M. Ewers, and P.T. Ganderton. 2004. Market prices for water in the semiarid west of the United States. Water Resour. Res. 40(9), https:// doi.org/10.1029/2003WR002846.

Boyle, T., D. Giurco, P. Mukheibir, A. Liu, C. Moy, S. White, and R. Stewart. 2013. Intelligent metering for urban water: A review. Water 5(3):1052-1081, https://doi.org/10.3390/w5031052.

Brelsford, C. and J.K. Abbott. 2017. Growing into water conservation? Decomposing the drivers of reduced water consumption in Las Vegas, NV. Ecol. Econ. 133:99-110, https://doi.org/10.1016/j. ecolecon.2016.10.012.

Buurman, J., M.J. Mens, and R.J. Dahm. 2017. Strategies for urban drought risk management: A comparison of 10 large cities. Int. J. Water Resour. Dev. 33(1): 31-50, https://doi.org/10.1080/07900 627.2016.1138398.

Cayan, D.R., T. Das, D.W. Pierce, T.P. Barnett, M. Tyree, and A. Gershunov. 2010. Future dryness in the southwest US and the hydrology of the early 21 st century drought. Proc. Natl. Acad. Sci. USA 107(50):21271-21276, https://doi.org/ $10.1073 /$ pnas.0912391107.

Cialdini, R.B., R.R. Reno, and C.A. Kallgren. 1990. A focus theory of normative conduct: Recycling the concept of norms to reduce littering in public places. J. Pers. Soc. Psychol. 58(6):1015, https:// doi.org/10.1037/0022-3514.58.6.1015.

Cialdini, R.B., L.J. Demaine, B.J. Sagarin, D.W. Barrett, K. Rhoads, and P.L. Winter. 2006. Managing social norms for persuasive impact. Soc. Influ. 1(1):3-15, https://doi.org/10.1080/15534510500 181459.

Clark, W.A. and J.C. Finley. 2008. Household water conservation challenges in Blagoevgrad, Bulgaria: A descriptive study. Water Int. 33(2):175-188, https://doi.org/10.1080/02508060802 023264 .

Cole, G. and R.A. Stewart. 2013. Smart meter enabled disaggregation of urban peak water demand: Precursor to effective urban water planning. Urban Water J. 10 (3):174-194, https://doi.org/10.1080/ 1573062X.2012.716446.

Corral-Verdugo, V., M. Frias-Armenta, F. Pérez-Urias, V. Orduña-Cabrera, and N. Espinoza-Gallego. 2002. Residential water consumption, motivation for conserving water and the continuing tragedy of the commons. Environ. Manage. 30(4):527535, https://doi.org/10.1007/s00267002-2599-5.

De Oliver, M. 1999. Attitudes and inaction: A case study of the manifest demographics of urban water conservation. Environ. Behav. 31(3):372-394, https://doi.org/10.1177/00139169921 972155 .

DeOreo, W.B., P.W. Mayer, B. Dziegielwski, and J.C. Kiefer. 2016. Residential uses of water. Water Res. Foundation, Denver, CO.

Dieter, C.A., M.A. Maupin, R.R. Caldwell, M.A. Harris, T.I. Ivahnenko, J.K. Lovelace, N.L. Barber, and K.S. Linsey. 2018. Estimated use of water in the United States in 2015. U.S. Geol. Serv. Circ. 1441, https://doi.org/10.3133/cirl441.

Dolan, P. and R. Metcalfe. 2015. Neighbors, knowledge, and nuggets: Two natural field experiments on the role of incentives on energy conservation. Becker Friedman Inst. Res. Econ. Working Paper 2589269. 23 Apr. 2021. <https:// papers.ssrn.com/sol3/papers.cfm? abstract_id=2589269 $>$.

Dolnicar, S. and A. Hurlimann. 2010. Australians' water conservation behaviors and attitudes. Australas. J. Water Resour. 14(1):43-53, https://doi.org/10.1080/ 13241583.2010.11465373.

Fan, Y., L. McCann, and H. Qin. 2017. Households' adoption of drought tolerant plants: An adaptation to climate change? J. Agr. Res. Econ. 42(2):236-254. https:// www.jstor.org/stable/44329752.

Festinger, L. 1954. A theory of social comparison processes. Hum. Relat. 7(2): 117-140, https://doi.org/10.1177/ 001872675400700202 .

Ferraro, P.J., J.J. Miranda, and M.K. Price. 2011. The persistence of treatment effects with norm-based policy instruments: Evidence from a randomized environmental policy experiment. Amer. Econ. Rev. 101(3):318-322, https://doi. org/10.1257/aer.101.3.318.

Fielding, K.S., A. Spinks, S. Russell, R. McCrea, R. Stewart, and J. Gardner. 2013. An experimental test of voluntary strategies to promote urban water demand management. J. Environ. Manage. 114:343-351, https://doi.org/ 10.1016/j.jenvman.2012.10.027.

Fielding, K.S., S. Russell, A. Spinks, and A. Mankad. 2012. Determinants of household water conservation: The role of demographic, infrastructure, behavior, and psychosocial variables. Water Resour. Res. 48(10), https://doi.org/10.1029/ 2012 WR012398.

Finley, S.L. and N.B. Basu. 2020. Curbing the summer surge: Permanent outdoor water use restrictions in humid and semiarid cities. Water Resour. Res. 56(8), https:// doi.org/10.1029/2019WR026466. 
Fu, J.M., J. Fry, and B.R. Huang. 2004. Minimum water requirements of four turfgrass in the transition zone. HortScience 39(7):1740-1744, https://doi. org/10.21273/HORTSCI.39.7.1740.

Geller, E.S., R.A. Winett, and P.B. Everett. 1982. Preserving the environment: New strategies for behavior change. J. Leis. Res. 14(4):365-366, https://doi.org/10.1080/ 00222216.1982 .11969535 .

Gilg, A. and S. Barr. 2006. Behavioral attitudes towards water saving? Evidence from a study of environmental actions. Ecol. Econ. 57(3):400-414, https://doi. org/10.1016/j.ecolecon.2005.04.010.

Goette, L., C. Leong, and N. Qian. 2019. Motivating household water conservation: A field experiment in Singapore. PLoS One 14(3): https://doi.org/ 10.1371/journal.pone.0211891.

Greene, W.H. and D.A. Hensher. 2010. Modeling ordered choices: A primer. Cambridge Univ. Press, Cambridge, UK.

Hugie, K.L. and E. Watkins. 2016. Performance of low-input turfgrass species as affected by mowing and nitrogen fertilization in Minnesota. HortScience 51(10): 1278-1286, https://doi.org/10.21273/ hortscil1007-16.

Iglesias, E. and M. Blanco. 2008. New directions in water resources management: The role of water pricing policies. Water Resour. Res. 44(6), https://doi.org/ 10.1029/2006WR005708.

Inman, D. and P. Jeffrey. 2006. A review of residential water conservation tool performance and influences on implementation effectiveness. Urban Water J. 3(3):127-143, https://doi.org/10.1080/1573062060096 1288.

Knuth, M., B.K. Behe, C.R. Hall, P.T. Huddleston, and R.T. Fernandez. 2018a. Consumer perceptions of landscape plant water sources and uses in the landscape during real and perceived drought. HortTechnology 28(1):85-93, https://doi. org/10.21273/HORTTECH03893-17.

Knuth, M., B.K. Behe, C.R. Hall, P.T. Huddleston, and R.T. Fernandez. 2018b. Consumer perceptions, attitudes, and purchase behavior with landscape plants during real and perceived drought periods. HortScience 53(1):49-54, https://doi. org/10.21273/HORTSCI12482-17.

Knuth, M., B. Behe, C. Hall, P. Huddleston, and R. Fernandez. 2019. Sit back or dig in: The role of activity level in landscape market segmentation. HortScience 54(10):1818-1823, https://doi.org/ 10.21273/HORTSCI14158-19.

Knuth, M.J., B.K. Behe, P.T. Huddleston, C.R. Hall, R.T. Fernandez, and H.
Khachatryan. 2020. Water conserving message influences purchasing decision of consumers. Water 12(12):3487, https:// doi.org/10.3390/w12123487.

Lam, S.P. 2006. Predicting intention to save water: Theory of planned behavior, response efficacy, vulnerability, and perceived efficiency of alternative solutions. J. Appl. Soc. Psychol. 36(11):2803-2824, https://doi.org/10.1111/j.0021-9029. 2006.00129.x.

Landon, A.C., G.T. Kyle, and R.A. Kaiser. 2016. Predicting compliance with an information-based residential outdoor water conservation program. J. Hydrol. (Amst.) 536:26-36, https://doi.org/10. 1016/j.jhydrol.2016.02.024

Lant, C.L. 1993. The social acceptability of water conservation in Springfield, Ill. J. Amer. Water Work. Assoc. 85(8):85-89, https://doi.org/10.1002/j.1551-8833. 1993.tb06045.x.

Mayer, P.W., W.B. DeOreo, E.M. Opitz, J.C. Kiefer, W.Y. Davis, B. Dziegielewski, and J.O. Nelson. 1999. Residential end uses of water. 23 Apr. 2021. <https:// www.sdu.dk/ /media/Files/Om_SDU/ Institutter/ITI/Forskning/NATO\%20AR W/Literature/Residential\%20end\%20uses_ of $\% 20$ water.pdf $>$.

Maupin, M.A., J.F. Kenny, S.S. Hutson, J.K. Lovelace, N.L. Barber, and K.S. Linsey. 2014. Estimated use of water in the United States in 2010. U.S. Geol. Serv. Circ. 1405, https://doi.org/10.3133/ cirl405.

McKelvey, R.D. and W. Zavoina. 1975. A statistical model for the analysis of ordinal level dependent variables. J. Math. Sociol. 4(1):103-120, https://doi.org/10.1080/ 0022250X.1975.9989847.

McKenzie-Mohr, D. 2000. Promoting sustainable behavior: An introduction to community-based social marketing. J. Soc. Issues 56(3):543-554, https://doi.org/ $10.1111 / 0022-4537.00183$.

Millock, K. and C. Nauges. 2010. Household adoption of water-efficient equipment: The role of socio-economic factors, environmental attitudes and policy. Environ. Resour. Econ. 46(4):539-565, https://doi.org/ 10.1007/s10640-010-9360-y.

Minnesota Department of Natural Resources. 2021a. Water conservation for residents. 23 Apr. 2021. <https://www. dnr.state.mn.us/waters/watermgmt_ section/appropriations/water-conservationresidents.html $>$.

Minnesota Department of Natural Resources. 2021b. Drought in Minnesota. 23 Apr. 2021. <https://www.dnr.state. mn.us/climate/drought/index.html $>$.
Minnesota Environmental Quality Board. 2015. Beyond the status quo: $2015 \mathrm{EQB}$ water policy report. 23 Apr. 2021. <https://www.eqb.state.mn.us/sites/ default/files/documents/WaterReport_ 091515_v2_0.pdf>.

Monteiro, J.A. 2017. Ecosystem services from turfgrass landscapes. Urban For. Urban Green. 26:151-157, https://doi. org/10.1016/j.ufug.2017.04.001.

Nieswiadomy, M.L. 1992. Estimating urban residential water demand: Effects of price structure, conservation, and education. Water Resour. Res. 28(3):609-615, https://doi.org/10.1029/91WR02852.

Nguyen, K.A., R.A. Stewart, H. Zhang, O. Sahin, and N. Siriwardene. 2018. Reengineering traditional urban water management practices with smart metering and informatics. Environ. Model. Softw. 101:256-267, https://doi.org/10.1016/ j.envsoft.2017.12.015.

Polsky, C., J.M. Grove, C. Knudson, P.M. Groffman, N. Bettez, J. Cavender-Bares, S.J. Hall, J.B. Heffernan, S.E. Hobbie, K.L. Larson, and J.L. Morse. 2014. Assessing the homogenization of urban land management withanapplicationtoUSresidentiallawncare. Proc. Natl. Acad. Sci. USA 111(12): 4432-4437, https://doi.org/10.1073/ pnas.1323995111.

Phyn. 2020. Residential water consumption spikes during COVID-19 pandemic. 23 Apr. 2021. <https://www.phyn. $\mathrm{com} /$ press/residential-water-consumptionspikes-during-covid-19-pandemic/>.

Renwick, M.E. and R.D. Green. 2000. Do residential water demand side management policies measure up? An analysis of eight California water agencies. J. Environ. Econ. Manage. 40(1):37-55, https:// doi.org/10.1006/jeem.1999.1102.

Russell, S. and K. Fielding. 2010. Water demand management research: A psychological perspective. Water Resour. Res. 46(5), https://doi.org/10.1029/2009WR 008408 .

Saurí, D. 2013. Water conservation: Theory and evidence in urban areas of the developed world. Annu. Rev. Environ. Resour. 38:227-248, https://doi.org/ 10.1146/annurev-environ-013113-142651.

Schultz, P.W. 2002. Knowledge, information, and household recycling: Examining the knowledge-deficit model of behavior change, p. 67-82. In: T. Dietz and P.C. Stern (eds.). New tools for environmental protection: Education, information and voluntary measures. Natl. Acad. Press, Washington, DC.

Schultz, P.W., J.M. Nolan, R.B. Cialdini, N.J. Goldstein, and V. Griskevicius. 2007. The constructive, destructive, and 
reconstructive power of social norms. Psychol. Sci. 18(5):429-434, https://doi. org/10.1111/j.1467-9280.2007.01917.x.

Schultz, P.W., A. Messina, G. Tronu, E.F. Limas, R. Gupta, and M. Estrada. 2016. Personalized normative feedback and the moderating role of personal norms: A field experiment to reduce residential water consumption. Environ. Behav. 48(5):686-710, https://doi.org/10.1177 /0013916514553835.

Seyranian, V., G.M. Sinatra, and M.S. Polikoff. 2015.Comparingcommunicationstrategiesfor reducingresidentialwaterconsumption.J.Environ. Psychol. 41:81-90, https://doi.org/ 10.1016/j.jenvp.2014.11.009.

Sudarshan, A. 2017. Nudges in the marketplace: The response of household electricity consumption to information and monetary incentives. J. Econ. Behav. Organ. 134:320-335, https://doi.org/ 10.1016/j.jebo.2016.12.015.

Su, K., D.J. Bremer, S.J. Keeley, and J.D. Fry. 2008. Rooting characteristicsand canopy responses to drought of turfgrasses including hybrid bluegrasses. Agron. J. 100(4):949-956, https://doi.org/ 10.2134 /agronj2007.0292.

Syme, G.J., Q. Shao, M. Po, and E. Campbell. 2004. Predicting and understanding home garden water use. Landsc. Urban Plan. 68(1):121-128, https://doi. org/10.1016/j.landurbplan.2003.08.002.
Takacs, D. 2018. When the well runs dry: Why water-rich states need to prepare for climate change and protect their groundwater. William Mary Environ. Law Policy Rev. 43:219-243, https://scholarship.law. wm.edu/wmelpr/vol43/issl/7.

Tom, G., G. Tauchus, J. Williams, and $S$. Tong. 2011. The role of communicative feedback in successful water conservation programs. Appl. Environ. Educ. Commun. 10(2):80-90, https://doi.org/10.1080/ $1533015 X .2011 .575632$.

University of Nebraska-Lincoln. 2021. U.S. drought monitor. 23 Apr. 2021. $<$ https://droughtmonitor.unl.edu/>.

U.S. Census Bureau. 2020. 2019 American community survey single-year estimates. 23 Apr. 2021. <https://www. census.gov/newsroom/press-kits/2020/ acs-lyear.html>.

U.S. Environmental Protection Agency. 2013. Reduce your outdoor water use. 23 Apr. 2021 . <https://19january 2017 snapshot.epa.gov/www3/watersense/docs/ factsheet_outdoor_water_use_508.pdf $>$.

U.S. Environmental Protection Agency. 2016. Tacking WaterSense: Outdoor water use. 23 Apr. 2021. < https://www. epa.gov/sites/default/files/2017-01/ documents/ws-commercial-webinar-slidesoutdoor-use.pdf $>$.

U.S. Environmental Protection Agency. 202 la. WaterSense: Outdoors. 23 Apr.
2021. <https://www.epa.gov/watersense/ outdoors $>$.

U.S. Environmental Protection Agency. 2021b. WaterSense: Statistics and facts. 23 Apr. 2021. <https://www.epa.gov/watersense/statistics-and-facts\#: : :text=Each $\%$ 20American $\% 20$ uses\%20an\%20average, water $\% 2$ Defficient $\% 20$ fixtures $\% 20$ and $\%$ 20 appliances $>$.

U.S. Government Accountability Office. 2014. Supply concerns continue, and uncertainties complicate planning. 23 Apr. 2021. <https://www.gao.gov/ assets/gao-14-430-highlights.pdf $>$.

U.S. Geological Survey. 2014. Background, appropriations, and issues for congress. 23 Apr. 2021. <https://www.everycrsreport. com/reports/R43777.html > .

Watkins, E., S. Fei, D. Gardner, J. Stier, S. Bughrara, D. Li, C. Bigelow, L. Schleicher, B. Horgan, and K. Diesburg. 2011. Low-input turfgrass species for the north central United States. Appl. Turfgrass Sci. 8(1):1-11, https://doi.org/10.1094/ ats-2011-0126-02-rs

Willis, R.M., R.A. Stewart, K. Panuwatwanich, P.R. Williams, and A.L. Hollingsworth. 2011. Quantifying the influence of environmental and water conservation attitudes on household end use water consumption. J. Environ. Manage. 92(8):1996-2009, https:// doi.org/10.1016/j.jenvman.2011.03.023. 


\section{Supplemental Material 1}

Water conservation messages in the landscape water use survey in the sevencounty metropolitan area in Minnesota. In the survey, each participant was randomly assigned to one of three messages that encourage water conservation. The content of messages is as follows:

Message A: Use water wisely message

Suppose you receive a use water wisely message and a piece of general information why one should use water wisely as follows:

Every society shares the responsibility to promote the sustainable use of water. There are many ways to save water:

- Washing a car using a bucket instead of hosing would save 8 gal per $5 \mathrm{~min}^{\mathrm{z}}$

- Storing runoff in rain barrels and using to water gardens between rain storms would save 50 gal per rain barrel.

- Replacing old dishwasher with WaterSense approved dishwasher would save up to 16 gal per load.

- Washing only full loads of clothing would save up to 20 gal per load if the washing machine is WaterSense approved.

- Sweeping sidewalks instead of hosing would save 2 gal per minute.

\section{Message B: Home water-use comparison}

Suppose you receive a feedback message as follows:

The average water consumption of your neighborhood is 3750 gal per person per month, whereas your water use in the last measurement period is 4500 gal per person per month, which is $20 \%$ higher than the average water use of your neighborhood.

Message C: Home water use comparison and rebate

Suppose you receive a feedback message as follows:

The average water consumption of your neighborhood is 3750 gal per person per month, whereas your water use for the last measurement period is 4500 gal per person per month, which is $20 \%$ higher than the statewide average water use.

You will receive a rebate of $\$ 5$ for every $5 \%$ water reduction in the current measurement period compared to last measurement period. For example, if you save $10 \%$ water use in this measurement period compared to the last measurement period, you could receive a rebate of $\$ 10$. The rebate can be used to pay for your future water bill.

${ }^{\mathrm{z}} 1 \mathrm{gal}=3.7854 \mathrm{~L}$. 